\title{
Cell wall characteristics during sexual reproduction of Mougeotia sp. (Zygnematophyceae) revealed by electron microscopy, glycan microarrays and RAMAN spectroscopy
}

\author{
Charlotte Permann $^{1}\left(\mathbb{D} \cdot\right.$ Klaus Herburger $^{2} \mathbb{D} \cdot$ Martin Niedermeier $^{3,4} \mathbb{D} \cdot$ Martin Felhofer $^{3}$ (D) Notburga Gierlinger $^{3}\left(\mathbb{D} \cdot\right.$. $^{-}$ \\ Andreas Holzinger ${ }^{1}$ (D)
}

Received: 11 February 2021 / Accepted: 23 April 2021 / Published online: 11 May 2021

(c) The Author(s) 2021

\begin{abstract}
Mougeotia spp. collected from field samples were investigated for their conjugation morphology by light-, fluorescence-, scanning- and transmission electron microscopy. During a scalarifom conjugation, the extragametangial zygospores were initially surrounded by a thin cell wall that developed into a multi-layered zygospore wall. Maturing zygospores turned dark brown and were filled with storage compounds such as lipids and starch. While M. parvula had a smooth surface, $M$. disjuncta had a punctated surface structure and a prominent suture. The zygospore wall consisted of a polysaccharide rich endospore, followed by a thin layer with a lipid-like appaerance, a massive electron dense mesospore and a very thin exospore composed of polysaccharides. Glycan microarray analysis of zygospores of different developmental stages revealed the occurrence of pectins and hemicelluloses, mostly composed of homogalacturonan (HG), xyloglucans, xylans, arabino-galactan proteins and extensins. In situ localization by the probe OG7$13^{\mathrm{AF}} 488$ labelled HG in young zygospore walls, vegetative filaments and most prominently in conjugation tubes and cross walls. Raman imaging showed the distribution of proteins, lipids, carbohydrates and aromatic components of the mature zygospore with a spatial resolution of $\sim 250 \mathrm{~nm}$. The carbohydrate nature of the endo- and exospore was confirmed and in-between an enrichment of lipids and aromatic components, probably algaenan or a sporopolleninlike material. Taken together, these results indicate that during zygospore formation, reorganizations of the cell walls occured, leading to a resistant and protective structure.
\end{abstract}

Keywords Cell wall $\cdot$ Conjugation $\cdot$ Mougeotia $\cdot$ Sexual reproduction $\cdot$ Streptophyte $\cdot$ Zygospore

\section{Handling Editor: Peter Nick}

In memory of Ursula Lütz-Meindl

Charlotte Permann and Klaus Herburger have contributed equally to this work.

Andreas Holzinger

Andreas.Holzinger@uibk.ac.at

1 Department of Botany, Functional Plant Biology, University of Innsbruck, 6020 Innsbruck, Austria

2 Department of Plant and Environmental Sciences, Section for Plant Glycobiology, University of Copenhagen, 1871 Frederiksberg, Denmark

3 Department of Nanobiotechnology, University of Natural Resources and Life Sciences Vienna (BOKU), 1190 Vienna, Austria

4 Department of Biomaterials, Max Planck Institute of Colloids and Interfaces, 14476 Potsdam, Germany

$\begin{array}{ll}\text { Abbreviations } \\ \text { AGP } & \text { Arabinogalactan protein } \\ \text { AIR } & \text { Alcohol-insoluble residue } \\ \text { BBM } & \text { Bold's Basal Medium } \\ \text { CA } & \text { Concanavalin A } \\ \text { DE } & \text { Degree of esterification } \\ \text { EGP } & \text { Endo-polygalacturonase } \\ \text { HG } & \text { Homogalacturonan } \\ \text { NMF } & \text { Non-negative matrix factorization } \\ \text { PL } & \text { Pectate lyase } \\ \text { RCA } & \text { Ricinus communis agglutinin } \\ \text { RGI } & \text { Rhamnogalacturonan I } \\ \text { SBA } & \text { Soybean agglutinin } \\ \text { UEA } & \text { Ulex europaeus agglutinin }\end{array}$

\section{Abbreviations}

BBM Bold's Basal Medium

DE Degree of esterification

EGP Endo-polygalacturonase

HG Homogalacturonan

NMF Non-negative matrix factorization

PL Pectate lyase

RCA Ricinus communis agglutinin

RGI Rhamnogalacturonan I

UEA Ulex europaeus agglutinin 


\section{Introduction}

Zygnematopyhceaen green algae have gained much attention as immediate sister group to land plants (Becker 2013; Cheng et al. 2019; Wodniok et al. 2011). With the publication of the first genomes of Spirogloea muscicola and Mesotaenium endlicherianum (Cheng et al. 2019), new insights into land plant evolution became available. The adaptation to a subareal/terrestrial habitat has particular requirements, and the horizontal gene transfer of e.g. GRAS genes from soil bacteria can be considered as a major step in achieving prerequisites for life on land. The draft genome of Penium margaritaceum gives further evidence for additional evolutionary steps necessary for terrestrialization, which includes several classes of carbohydrate active enzymes (CAZy) (Jiao et al. 2020), and reflects Penium as a model in cell wall research (e.g. Domozych et al. 2014).

In contrast, the process of conjugation, a characteristic form of sexual reproduction in Zygnematophyceae, and the formation of resistant zygospores and their cell wall composition is only poorly understood. Conjugation involves the fusion of two gametes, which lack organelles for locomotion, and does not directly depend on the availabilty of water (Kadlubowksa 2009; Takano et al. 2019). Conjugation can be performed scalariform ("ladder-like" conjugation), where two different filaments are oriented parallel to each other and fuse their gametes via a conjugation tube; alternatively, it involves two cells from the same filament (Kadlubowska 2009). In the latter case, a distinction between lateral and terminal is made, based on the origin of the conjugation tube. Further distinctions can be made based on the location of gamete fusion and zygospore formation (Kadlubowska 2009). Zygospores are the immediate product of this unique process of sexual reproduction found in Zygnematophyceae. These spores differ in their form, colour and structure, highlighting their importance in species determination (e.g. Stancheva et al. 2013, 2016; Stancheva and Sheath 2012; Takano et al. 2019). The presumed ability of zygospores to endure unfavourable conditions better than asexually formed resting spores is probably found in their multi-layered thick cell wall (Kadlubowska 2009). The complex zygospore wall is composed of three major layers, the endo-, meso- and exospore, which are differentiated by their chemical composition (Simons et al. 1984). While the colourless exoand endospore are hypothesized to contain cell wall polysaccharides such as cellulose and/ or pectins, the brown or blue coloured interjacent mesospore is frequently ornamented and might consist of algaenan (Poulícková et al. 2007). Algaenan is a resistant biopolymere quite similar to sporopollenin, found in the outer walls of pollen and spores (Montgomery et al. 2016; Poulícková et al. 2007). Unfortunately, the induction of conjugation under laboratory conditions is difficult and was successful only in a few genera like Spirogyra sp. (e.g. Takano et al. 2019). It involves a wide range of internal and external factors, making field sampling an important alternative (Gauch 1966; Grote 1977; Simons et al. 1984; Stabenau and Säftel 1989; Yamashita and Sasaki 1979).

In the present study, we selected Mougeotia sp. to investigate the process of conjugation, the formation of zygospores and their ultrastructural details in field-collected samples. Mougeotia sp. has a long tradition as a cell biological research system and some experiments were groundbreaking for understanding the chloroplast positioning mechanisms, phytochrome research and cytoskeletal involvement in these processes (e.g. Serlin and Roux 1984; Wagner and Klein 1981; Wagner et al. 1972 and references therein). Recently, a transient transformation system was established in Mougeotia scalaris (Regensdorff et al. 2018).

In this work, we addressed the following questions, (a) how does sexual reproduction take place in field sampled Mougeotia sp. and (b) what is the structural basis for the resistance of zygospores? We addressed this by elucidating the chemical composition of the multi-layered zygospore wall. We hypothesize, that the resistance of these zygospores is related to the chemical composition of the mesospore and that the exospore and the modified conjugation tube have a prominent role during the development of the zygospores. We performed a comprehensive light-microscopical investigation of the conjugation process and zygospore formation by scanning- and transmission electron microscopy (SEM/TEM) to investigate the ultrastructure of the resulting zygospores. We then used Comprehensive Microarray Polymer Profiling (CoMPP) to get insights into the cell wall polysaccharide composition. We furthermore performed a set of cell wall probes to localize abundant cell wall polymers in situ. To get additional insights into the distribution of carbohydrates, lipids, proteins and aromatic components, we applied Raman spectroscopy. With this multi-technical approach, we provide new information for the structural basis for Zygnematophyceaen zygospore resistance.

\section{Material methods}

\section{Algal material}

Algal mats containing Zygnematophyceae were collected at two field sites in the Kühtai valley (Tirol, Austria) in the months May to November 2019/2020. The sampling sites were slow running rivulets or shallow pools of water. In total, 62 samples were taken, of which five contained zygospores or conjugating stages of Mougeotia spp. These mats were labelled chronologically by sampling date $1-5$ (for additional information see 
Suppl. Table S1). Mat 1, containing sample 1, grew in a small streamlet near a natural trail $\left(47^{\circ} 19^{\prime} 56^{\prime \prime} \mathrm{N}, 11^{\circ} 09^{\prime} 84^{\prime \prime} \mathrm{E}\right)$, while mats 2-5 were located in marshy terrain near the main road leading to the Kühtai village in Tyrol, Austria $\left(47^{\circ} 21^{\prime} 76^{\prime \prime} \mathrm{N}\right.$, $\left.11^{\circ} 03^{\prime} 77^{\prime \prime} \mathrm{E}\right)$. The collected samples were stored in water taken from the sampling sites at a $16 / 8 \mathrm{~h}$ light-dark regime, $20 / 15^{\circ} \mathrm{C}$ and $\sim 30 \mu \mathrm{mol}$ photons $\mathrm{m}^{-2} \mathrm{~s}^{-1}$ PAR.

\section{Light-and fluorescence microscopy}

Light microscopical investigations of the field sampled Mougeotia spp. filaments and zygospores were taken in the following three days after collecting, respectively. The maturation process was observed over a total period of four months, with images taken every 40 days. The analyses were performed using a Zeiss Axiovert $200 \mathrm{M}$ light microscope (Carl Zeiss AG, Jena, Germany), equipped with an Axiocam HRc camera (Carl Zeiss AG, Jena, Germany) and Zeiss Axiovision software. Chlorophyll autofluorescence was visualized with a Zeiss Filter Set 09 (excitation: band pass (BP) 450-490 nm and emission: long pass (LP) $515 \mathrm{~nm}$ ). A $1 \%$ calcolfluor white (Fluka Analytical, Cat\# 18,909) staining following the protocol of Herburger and Holzinger (2016) was applied for cellulose and callose detection. The stained cells were than investigated using a Zeiss Filter Set 01 (excitation: BP 359-371 nm and emission: LP $397 \mathrm{~nm}$ ). For mucilage sheath detection, stainings with Indian ink (Dr. Ph. Martin's, Oceanside, USA) were performed.

\section{Scanning-and transmission electron microscopy}

Chemical fixation followed the protocol of Holzinger et al. (2006). Briefly, the cells were fixed in $2.5 \%$ glutaraldehyde in $20 \mathrm{mM}$ cacodylate buffer $(\mathrm{pH}=7)$ (Fluka, BioChemika, \#49,625; Sigma, \#C-0125) and embedded in 3\% agarose. Then they were post fixed in $1 \% \mathrm{OsO}_{4}$ (Serva, \# 31,251) in $20 \mathrm{mM}$ cacodylate buffer at $4{ }^{\circ} \mathrm{C}$ over night and dehydrated in increasing ethanol concentrations and transferred to propylene oxide. Fixed samples where embedded in modified SPURR's resin (Spurr 1969) (Science Services, \#14,300). Ultrathin sections were prepared using a Reichert Ultracut (Leica Microsystems, Wien, Austria), counterstained with $2 \%$ uranyl acetate and Reynold's lead citrate and investigated with a Zeiss Libra 120 transmission electron microscope (Carl Zeiss AG, Oberkochen, Germany) at $80 \mathrm{kV}$, which was equipped with a $2 \times 2 \mathrm{k}$ digital high speed camera and operated by ImageSP software (Albert Tröndle Restlichtverstärker Systeme, Moorenweis, Germany). For scanning electron microscopy, the samples were vapour-plated with gold with a Leica EM SCD050 sputter (Leica Mikrosysteme Ges.m.b.H., Vienna, Austria) and then investigated with a Zeiss EVO 10 SEM (Carl Zeiss AG, Jena, Germany). Due to the risk of sample material loss, the zygospores were directly treated with $70 \%$ ethanol instead of a gradual concentration increase for scanning electron microscopy investigations. This procedure did not seem to affect the morphological features of matured zygospores.

\section{Cell wall extraction and glycan micro array analysis}

Field collected $M$. disjuncta samples containing filaments and zygospores were freeze-dried (CoolSafe 15L freeze dryer; LaboGene A/S, Allerød, Denmark) and the alcohol-insoluble residue (AIR) was prepared by washing in $75 \%$ ethanol until the supernatant was transparent. Subsequent glycan array analysis (Moller et al. 2007) was done as described in detail before (Kračun et al. 2017). Briefly, cell wall components were sequentially extracted from AIR using $50 \mathrm{mM}$ CDTA (solubilizing pectic compounds) and $4 \mathrm{M} \mathrm{NaOH}$ (extracting hemicelluloses). Arrays were printed on nitrocellulose sheets using an ArrayJet Sprint microarray printer (ArrayJet, Roslin, UK). Printed arrays were probed with a set of antibodies (Rydahl et al. 2018; Suppl. Table S2). For controls, primary antibodies were omitted or heat-inactivated prior use. The experiment was repeated three times.

\section{Immunostaining}

Mougeotia disjuncta zygospores and filaments were immobilized on 12-well slides (ER202W, Thermo Fisher), coated with Vectabond (SP-1800-7, Vector Laboratories) and blocked in $0.5 \%(\mathrm{w} / \mathrm{v})$ bovine serum albumine (BSA) for $30 \mathrm{~min}$, washed three times in a droplet of Bold's Basal Medium (BBM) ( $\mathrm{pH} \mathrm{6.7)} \mathrm{for} 10 \mathrm{~min}$ and incubated with a primary antibody diluted 1:10-1:50 in BBM for $90 \mathrm{~min}$. Samples were rinsed with a syringe spray of BBM, washed $(3 \times 10 \mathrm{~min}$ in BBM$)$ and blocked as described above. Cells were then incubated with a secondary antibody for $90 \mathrm{~min}$ in the dark (1:500 in BBM; goat anti-rat $\operatorname{IgG}(\mathrm{H}+\mathrm{L})$ or IgM, AF488 conjugate (A11006, A21212) or goat antimouse AF488 (A28175); Thermo Fisher). After rinsing with a syringe $B B M$ spray and washing $(3 \times 10 \mathrm{~min}$ in $\mathrm{BBM})$, samples were mounted in BBM and antibody binding was visualized using an Olympus BX41 microscope connected to an Olympus U-RFL-T and GXCAM Hichrome-Met AF (FITC filter cube) or with a Leica SP5 confocal laser scanning microscope equipped with an argon (488 nm) laser. For controls, the primary antibody was heat-inactivated prior use (Suppl. Fig. S2 in situ controls).

\section{Cell wall staining using $0 \mathrm{G7}-13^{\mathrm{AF} 488}$ probe}

Immunostainings were complemented with the OG7$13^{\mathrm{AF} 488}$ probe, which binds long stretches of endogenous demethylated $\mathrm{HG}$ via a $\mathrm{Ca}^{2+}$-mediated process; the resulting 
complexes resemble HG 'egg boxes' (Mravec et al. 2017a, b). Mougeotia disjuncta cells were immobilized on Vectabond-coated 12-well slides and probed with $0.5 \mu \mathrm{ml}-1$ OG7-13 ${ }^{\mathrm{AF} 488}$ in BBM (pH 6.7) in the dark. After 60 min, samples were rinsed with a syringe spray of BBM and washed $(3 \times 10 \mathrm{~min}$ in $\mathrm{BBM})$. Samples were mounted in $\mathrm{BBM}$ and imaged using an Olympus BX41 microscope (FITC filter cube). For control samples, OG7-13 ${ }^{\mathrm{AF} 488}$ was omitted or replaced by cellohexaose conjugated with AF488.

\section{Confocal Raman microscopy}

Raman imaging of living $M$. disjuncta zygospores (embedded in heavy water $\left(\mathrm{D}_{2} \mathrm{O}\right)$ ) was performed on a confocal Raman microscope (Alpha300RA, WITec GmbH, Germany). The excitation light source was a linear polarized $\left(0^{\circ}\right)$ coherent compass sapphire VIS laser with $\lambda_{\mathrm{ex}}=532 \mathrm{~nm}$ (WITec GmbH, Germany) focused through a $100 \times$ oil immersion objective (numerical aperture $=1.4$, coverslip corrected $0.17 \mathrm{~mm}$ ) (Carl Zeiss, Germany). The backscattered Raman signal was directed through an optic multifiber (50 $\mu \mathrm{m}$ diameter) to a spectrometer (UHTS $300 \mathrm{WITec}$, Germany) (600 $\mathrm{g} \mathrm{mm}^{-1}$ grating) and finally to the CCD camera (Andor DU401 BV, Belfast, Northern Ireland). All Raman measurements were taken with a lateral resolution of $\sim 330 \mathrm{~nm}$ by acquiring at every pixel one full wavenumber spectrum with a laser power of $15 \mathrm{~mW}$ and an integration time of $0.18 \mathrm{~s}$. The Control Four (WITec GmbH, Germany) acquisition software was used for the Raman measurements set up. Raman data analysis was performed using the WITec Project Plus 4.1 software (WITec GmbH, Germany). After cosmic ray removal and baseline correction non-negative matrix factorization (NMF) was applied using four to seven endmembers to retrieve the most pure chemical components and visualize their distribution within the area of interest (Prats-Mateu et al. 2018).

\section{Results}

\section{Morphological investigations illustrate all conjugation stages and reveal major changes in cell content and cell wall structure during maturation}

Based on morphological species assignment, sample 1 from sampling site 1 was determined as Mougeotia parvula, while samples 2-5, which were all taken from the same sampling site, were determined as Mougeotia disjuncta. Mougeotia parvula posseses 6-13 $\mu \mathrm{m}$ wide vegetative cells, containing chloroplasts with several pyrenoids arranged in a row (Kadlubowska 2009). Zygospores are spherical in shape with a smooth, brown mesospore, measuring 13-36 $\mu \mathrm{m}$. The occurance of parthenospores has also been reported in this species in some cases. M. parvula has a cosmopolitan distribution, inhabiting sites up to $2360 \mathrm{~m}$ a.s.l. It is presumably the most common species of the genus. $M$. disjuncta features vegetative cells with a width of 14-18 $\mu \mathrm{m}$ and chloroplasts with 2-8 pyrenoids arranged in a row. The $24-32 \times 21-28 \mu \mathrm{m}$ zygospores are compressed-globose surrounded by a thick pectic substance. A distinct suture is located on the punctated, chestnut brown surface. This species is mostly known from Europe, the USA (Florida, Fort Meyers) and China (Kadlubowska 2009).

Sexual reproduction and zygospore formation occurred throughout the entire sampling period (May-September) and was always identified as scalariform isogamous extragametangial. M. disjuncta was used to illustrate all conjugation stages, which started with the formation of a papilla (Fig. 1a). The protruding papillae fused between aligned filaments and formed the conjugation tube, resulting in a ladder-like appearance (Fig. 1b). The cytoplasma of both conjugating cells (gametes) migrated into the conjugation tube, where they merged and the zygospore began to develop (Fig. 1c-f). After zygospore formation the closed conjugation tube formed suspensors, keeping the zygospores attached to the filaments (Fig. 1e, arrow). Staining M. disjuncta with commercial Indian ink (Dr. Ph. Martin's Bombay blue) revealed a prominent characterisitc gelatinous sheath (Fig. 1g, h).

The emerging zygospores were enclosed by a thin single-layered cell wall, resembling those of vegetative cells (Fig. 1f, i, m). The zygospores were also still green and showed red chlorophyll autofluorescence (Suppl. Fig. S1a, b). Calcofluor White was used to localize the cell walls of zygospores (Suppl. Fig. S1c, d). During a 4-month maturation process, the zygospores of both species turned yellowish-brown and became surrounded by a thick multi-layered cell wall (Fig. 1i-l M. parvula, Fig. 1m-p M. disjuncta). An accumulation of storage compounds such as lipid bodies and starch grains was clearly visible in older spores (Fig. 11, p). The germination process of these matured zygospores was observed in other samples of M. disjuncta. The process started with the rupture of the zygospore along the suture line, splitting the wall into two equal parts (Fig. 1q). The two halves where then pressed apart by its growing content and a newly formed vegetative filament was released (Fig. 1r, s).

\section{Mougeotia spp. zygospores differ in their surface ornamentation but coincide in their inner multilayered cell wall structure}

The scanning electron micrographs depicted different surface structures, assisting with morphological species determination. Sample 1, containing zygospores determined as M. parvula, showed a round appearance and surface with no exceptional features (Fig. 2a). On the other hand, zygospores of $M$. disjuncta were compressed-globose and characterized 
Fig. 1 Conjugation stages and zygospores of Mougeotia spp.. M. disjuncta ( $a-h, m-s)$, M. parvula $(i-l)$, conjugation process leading to zygospore formation $(a-f), 4$-month maturation process $(i-p)$. (a) formation of a papilla, (b) formation of conjugation tube, (c) beginning gamete fusion in conjugation tube, (d) gamete fusion, (e) zygospore formation final stage (suspensor, formed from closed conjugation tube is indicated by an arrow), (f) freshly formed zygospore, (g) sheath around zygospores inaccesible for India Ink staining, (h) zygospore encased in a gelatinous sheath visualized with India Ink staining, $(\mathbf{i}, \mathbf{m})$ $0 \mathrm{~d},(\mathbf{j}, \mathbf{n}) 40 \mathrm{~d},(\mathbf{k}, \mathbf{o}) 80 \mathrm{~d},(\mathbf{l}$, p) $120 \mathrm{~d}$, (q) zygospore wall split in half along suture line, (r) germinating zygospore, (s) freshly formed filament released from its zygospore. Abbreviation: papilla. Scale bars (a-f, h-s) $20 \mu \mathrm{m}$, (g) $100 \mu \mathrm{m}$
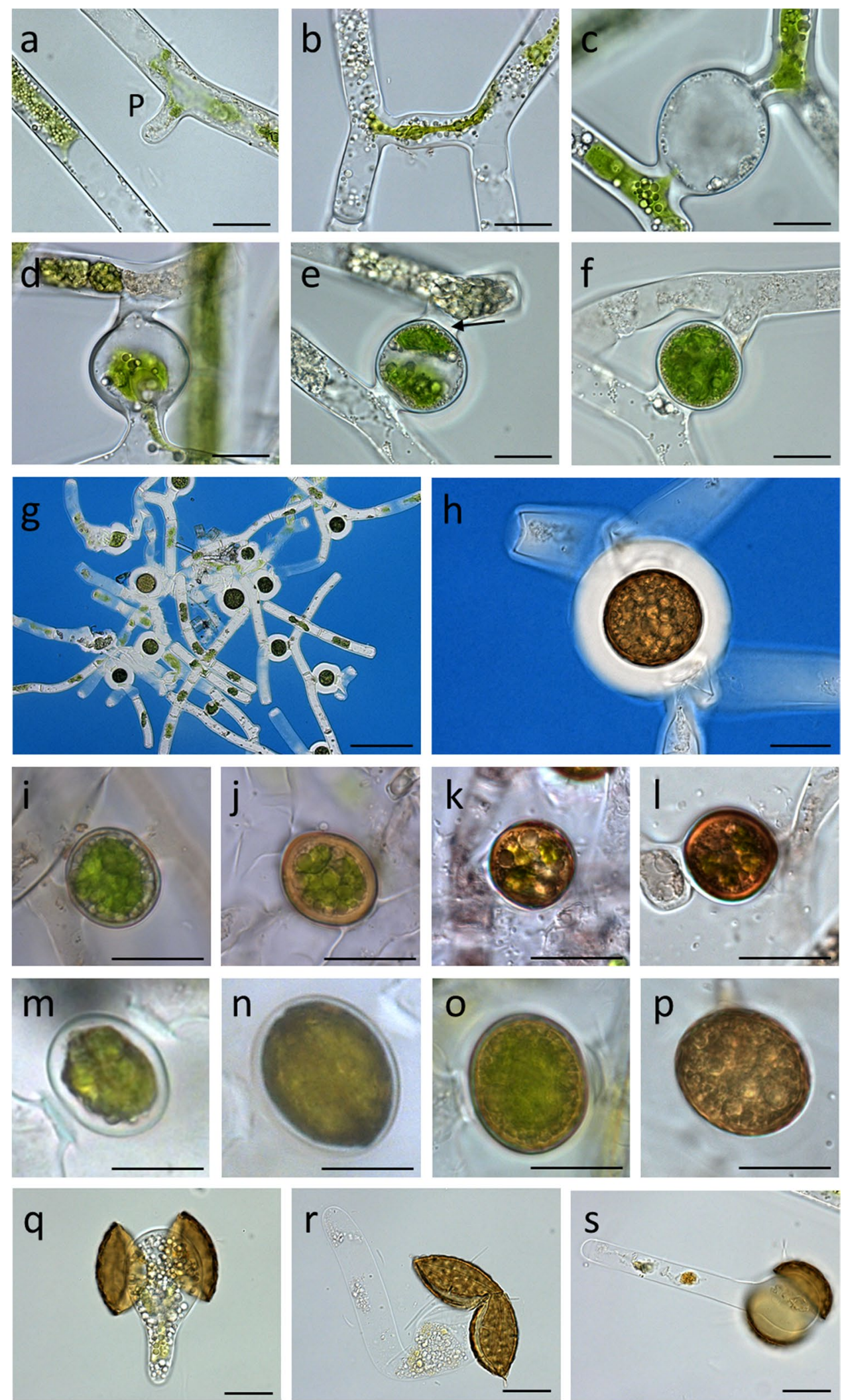

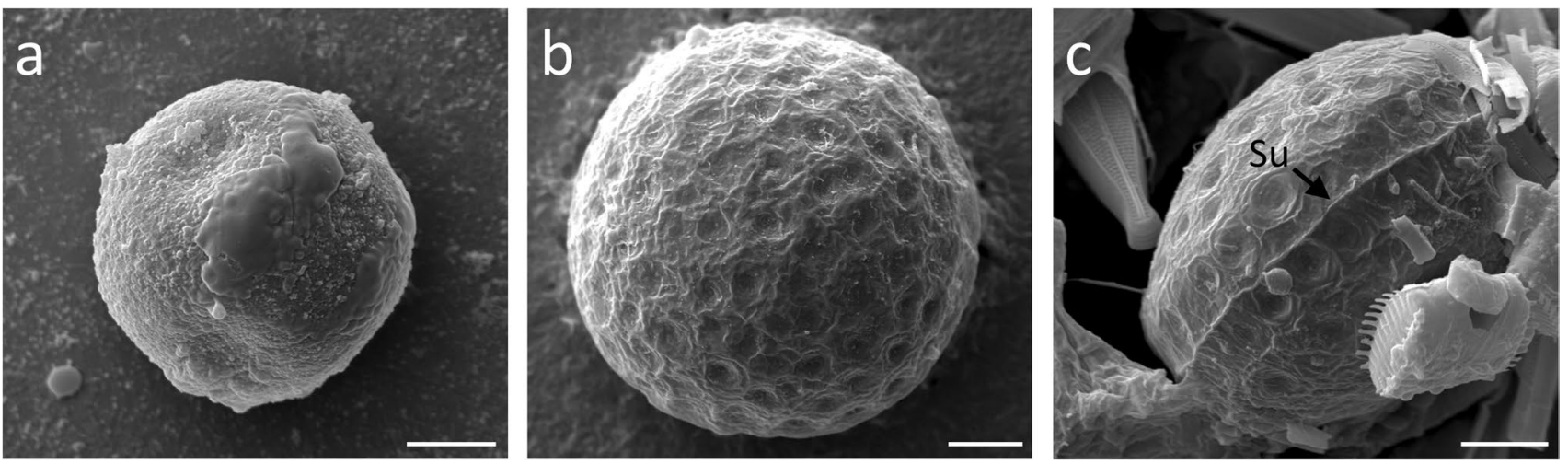

Fig. 2 Scanning electron micrographs of Mougeotia spp.. (a) M. parvula, (b) M. disjuncta zygospore with a micropunctate surface structure, (c) M. disjuncta zygospore displaying a suture. Abbreviation: Su suture. Scale bars $5 \mu \mathrm{m}$

by a micropunctate surface structure and a prominent suture (Fig. 2b, c). Transmission electron micrographs of young $M$. parvula zygospores showed large lipid bodies, starch grains, and chloroplast lobes in the cytoplasma as well as a thin polysaccharide-rich cell wall (Fig. 3a). As they matured the incipient development of an additional spore layer was visible (Fig. 3b). Fully developed zygospores of Mougeotia spp. displayed the three major layers, endo-, meso-, and exospore (Fig. 3c, e). The outermost thin layer, the exospore, formed a loose, probably amorphous structure on top of the mesospore. The mesospore showed a high electron density and the internal compartmentation in rhomboid blocks was occasionally visible (Fig. 3c). This structure seemed to define the zygospore's surface ornamentation (Fig. 3f). The inner layer, the endospore, was less electron dense, but appeared different in the two species, being considerably thicker in $M$. parvula (Fig. 3c, e). In both species, a thin lipid-like layer was located between the endo- and mesospore (Fig. 3c-g). The lipid bodies were spread throughout the cell lumen of mature zygospores or accumulated at the periphery close to the endospore (Fig. 3d, f).

\section{Mougeotia exhibits a chemically diverse cell wall architecture}

We subjected field-collected $M$. disjuncta samples to carbohydrate microarray profiling to test for the presence of $>40$ cell wall epitopes (Suppl. Table S1). Each sample contained both, filaments and zygospores, which allowed us to gain a comprehensive overview of the algal cell wall composition in the vegetative and the generative stage (Fig. 4). The CDTA fraction was rich in pectin and yielded very abundant binding of JIM5 and LM19 (homogalactauronan (HG) with low DE) and binding of LM20 (HG with higher DE) and INRA-RU1 + 2 (rhamnogalacturonan I (RGI)). Correspondingly, binding was also found for LM16, which recognizes an arabinose-rich side chain of RGI. Furthermore, CDTA extraction yielded glycoproteins as recognized by JIM8, JIM13 and LM14 (arabinogalactan proteins; AGPs), and by LM3, JIM11, JIM12 and JIM20 (extensins). The $\mathrm{NaOH}$ fraction was rich in hemicelluloses/ $\beta$-glucans, yielding abundant binding of probes targeting xyloglucans (LM15, LM25), and callose (BS-400-2). The weaker, yet appreciable binding was found for xylan probes (LM10, LM11) and scarce binding for mannan probes (BS400-4, LM21). Both the CDTA and $\mathrm{NaOH}$ fraction yielded a weak CBM2a and CBM3a signal, suggesting the extraction of cellulose. None of the tested lectins produced binding signals.

\section{In situ cell wall probing suggest a complex cell wall architecture in Mougeotia}

Based on our carbohydrate microarray profiling experiments, we selected probes that showed strong binding and subjected $M$. disjuncta filaments and zygospores to in situ stainings (Fig. 5). JIM5 and LM19 (recognizing HG with a low DE) delivered the strongest profiling signals. We selected LM19 as a more recently developed HG probe and confirmed abundant probe binding to algal filaments, with a maximum in conjugation tubes (Fig. 5a). Staining was also found in an outer wall layer for $\sim 50 \%$ of zygospores, indicating different zygospore developmental stages in our sample and a highly dynamic cell wall metabolism in the generative stage. We complemented our antibody staining with another HG probe (OG7-13 ${ }^{\mathrm{AF} 488}$ ), which binds de-methylated HG and reproduced the LM19 results: Strong binding to filaments and conjugation tubes and to $\sim 50 \%$ of zygospores (Fig. 5b). OG7-13 ${ }^{\mathrm{AF} 488}$ is a very small probe (oligosaccharide), which allows for a deeper penetration of cellular structures when compared to larger antibodies. However, we did not observe the staining of inner cell wall layers, suggesting that HG is restricted to outer layers and/or the dense cell wall cannot be penetrated by small 

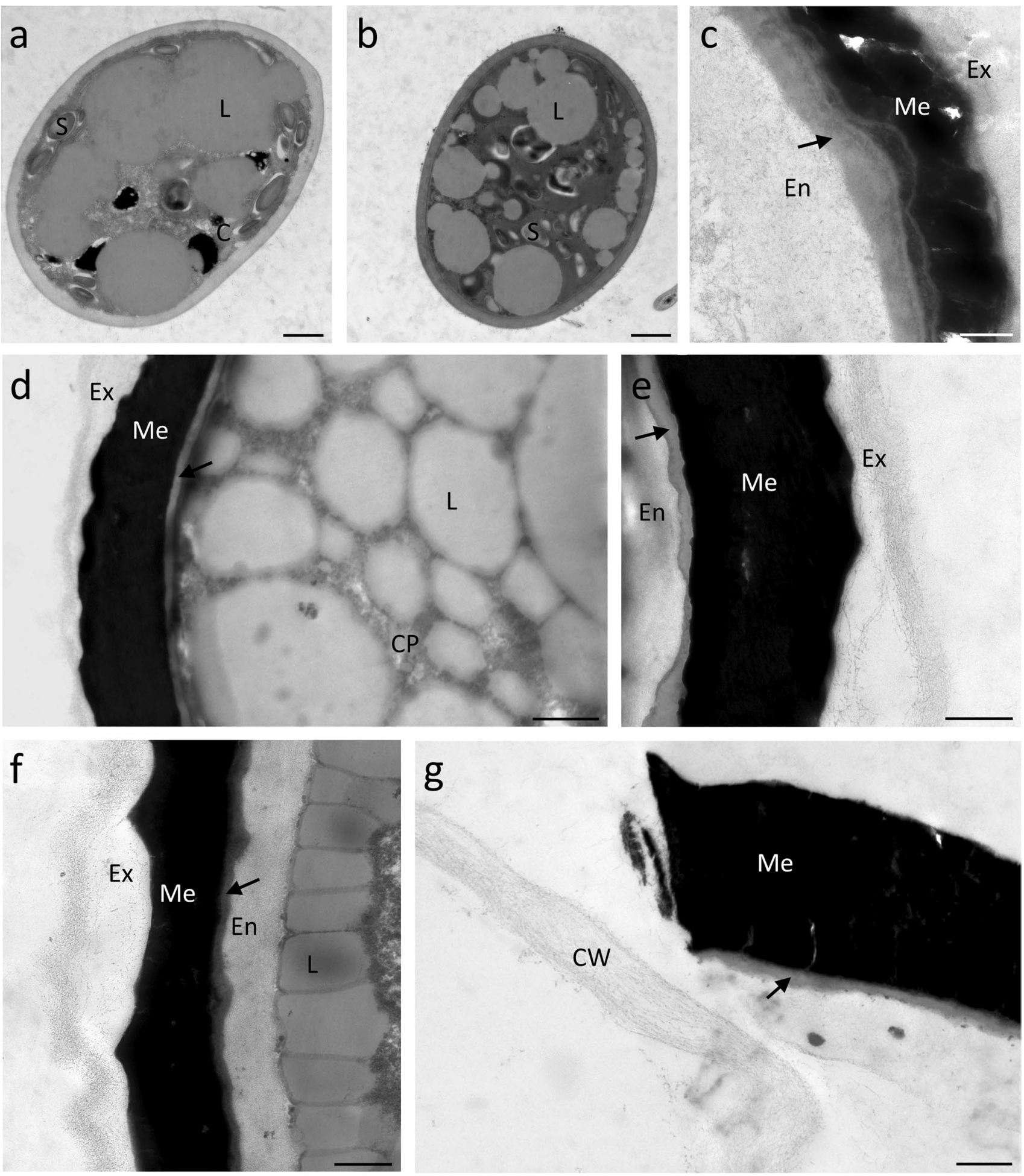

g

Fig. 3 Transmission electron micrographs of Mougeotia spp.. M. parvula $(a-c), M$. disjuncta $(d-g)$. (a) young zygospore with single layered cell wall, (b) maturing zygospore showing the incipient development of a multilayered cell wall, (c) detail view of mature zygospore wall, (d) zygospore with lipid bodies spread through cell lumen, (e) detail view of mature zygospore wall, (f) detail view of zygospore wall with lipid bodies accumulated at the periphery of the cytoplasm, (g) pried open zygospore releasing a newly formed filament. Abbreviations: C chloroplast, CP cytoplasma, L lipid body, S starch grain, En endospore, Ex exospore, Me mesospore, arrow indicates a lipidlike fourth layer. Scale bars (a, b, d) $1 \mu \mathrm{m},(\mathrm{c}, \mathrm{e}-\mathrm{g}) 500 \mathrm{~nm}$ 
Fig. 4 Determining cell wall epitopes in Mougeotia disjuncta using carbohydrate array profiling. $>40$ cell wall probes were incubated with CDTA and $\mathrm{NaOH}$ extracts prepared from Mougeotia AIR. The heatmap colour intensity represents the and is directly correlated to the numerical value. The strongest signal was assigned value 100 and the cut-off signal set to 5 . Probe codes are in bold and epitopes in brackets. Abbreviations: Ara arabinose, DE degree of esterification, Fuc fucose, Gal galactose, GalA galacturonic acid, GalNAc N-acetylgalactosamin, GlcA glucuronic acid, HG homogalacturonan, RGI rhamnogalacturonan I, Rha rhamnose, AGP arabinogalactan protein. Oligosaccharide nomenclature for xyloglucan probes see Fry et al. (1993) strength of the probe binding

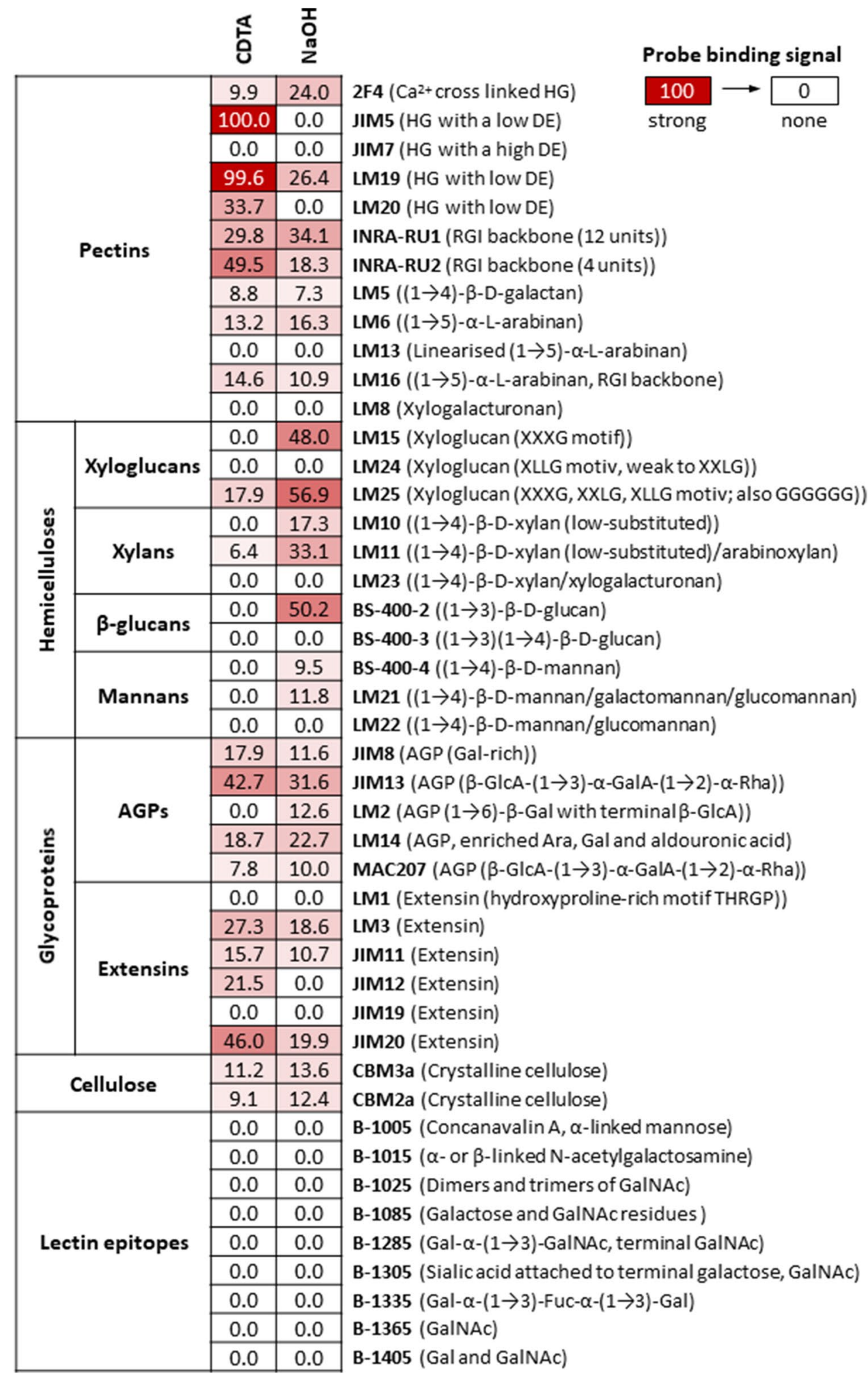

probes. Subjecting samples to HG digestion with pectate lyase (PL) and endo-polygalacturonase (EPG) prior OG7$13^{\mathrm{AF} 488}$ labelling diminished binding signals and staining was restricted to loosely attached cell wall remnants (Fig. 5c). This confirms HG occurs in both filament and zygospore walls.

\section{Comprehensive microarray polymer profiling shows high abundance of homogalacturonan, xyloglucan, arabino glactan proteins and extensins}

Our carbohydrate microarray profiling experiments showed that some of the cell wall probes produced signals in both 

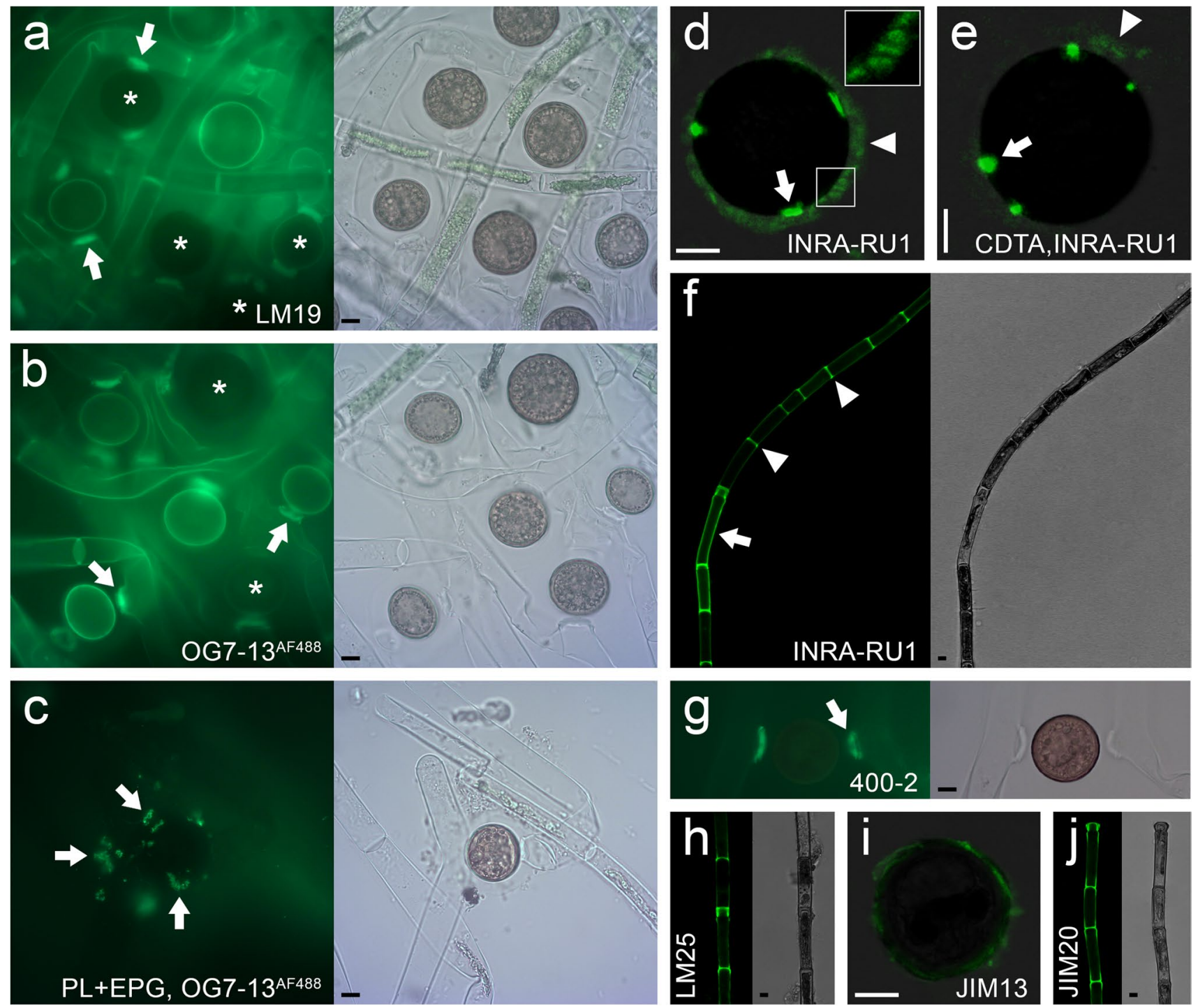

Fig. 5 In situ labelling of Mougeotia disjuncta cell walls. Fluorescent images (green) are shown on the left and corresponding bright field images on the right $(a-c, f-h, j)$ or were merged $(d, e, i)$. Images were taken with an epifluorescence microscope $(a-c, g)$ or confocal microscope $(d-f, h-i)$. (a) LM19 (recognises HG with low DE) binding to filaments (arrows: suspensor) and zygospores. 50\% of zygospores with weak/no signal (asterisks), (b) OG7-13 ${ }^{\mathrm{AF} 488}$ (demethylated HG) staining with similar results as in (a): strong staining of suspensor (arrows) and weak signal in some zygospores (asterisks), (c) OG7$13^{\mathrm{AF} 488}$ staining of cell wall remnants (arrows) after HG removal via PL and EPG, (d) INRA-RU1 (RGI) binding to outer sheath (arrow-

the CDTA and $\mathrm{NaOH}$ fraction (Fig. 4), suggesting that the respective epitopes were tightly integrated into the cell wall and/or part of different cell wall domains. For example, INRA-RU1 (RGI) produced similar signals in CDTA and $\mathrm{NaOH}$ fractions (Fig. 4). In situ staining revealed INRARU1 binding in (1) an outer zygospore sheath, suggesting the presence of fibrous RGI structures and in (2) highly localized spots inside the sheath (Fig. 5d). Treating zygospores with head) with fibrous structure (inlet) and in inner areas (arrow), (e) Some staining in outer sheath after CDTA extraction (arrowhead) close to staining spots in inner wall layer (arrow), (f) INRA-RUI (RGI) signal mainly restricted to cross cell walls (arrowheads); occasionally, whole cell wall areas with signal (arrow), (g) 400-2 (callose) signal in suspensor, (h) LM25 (xyloglucan) signal in cross cell walls, (i) JIM13 (AGP) binding in outer zygospore wall with fibrous appearance, (j) JIM20 (extensin) binding in areas around cross cell walls. Abbreviations: DE degree of esterification, EPG endo-polygalacturonase, HG homogalacturonan, PL pectate lyase, RGI rhamnogalacturonan I, AGP arabinogalactan protein. Scale bars $10 \mu \mathrm{m}$

CDTA prior staining, removed INRA-RU1 epitopes from the sheath, while the highly localized spots inside remained (Fig. 5e). We hypothesize that the highly localized staining sides represent RGI secretion hotspots, which help building up the sheath and thus contain local accumulations of RGI epitopes. This interpretation is supported by the observation that even after CDTA treatment, INRA-RU1 shows some sheath binding close to proposed 'secretion sites' (Fig. 5e). 
INRA-RU1 binding to filaments was heterogeneous. While for most cells, we only found binding to cross cell walls, some cells showed probe binding in both cross- and longitudinal walls (Fig. 5f).

We next tested non-pectin probes, finding strong binding for BS-400-2 (callose) to conjugation tubes (Fig. $5 \mathrm{~g}$ ). In contrast, other filament cell wall areas and zygospores produced very weak signals. The xyloglucan probe LM25 labelled cross cell walls (Fig. 5h). Finally, we examined the glycoprotein probes JIM13 (strongest AGP signal) and JIM 20 (strongest extensin signal; Fig. 4). JIM13 stained the zygospore sheath, producing a fibrous labelling pattern (Fig. 5i), while JIM20 stained areas in and around cross cell walls (Fig. 5j). This suggests that both filaments and zygospore cell walls contain glycoproteins.

\section{Raman spectroscopy reveals aromatic compounds in the cell wall}

To elucidate the chemical nature of the multi-layered zygospore wall, confocal Raman microscopy combined with advanced multivariate data analysis was performed (PratsMateu et al. 2018). Cells were scanned with a spatial resolution of $330 \mathrm{~nm}$ (Fig. 6a) and analysed with focus on the outer cell wall (Fig. 6b-c). Non-negative Matrix Factorization (NMF) unmixes proteins, carbohydrates, lipids and aromatics as the main chemical components of the entire zygospore (Fig. 6a and Suppl. Fig. S3). Proteins are represented by an endmember spectrum with protein and nucleic acid bands at 1008,1459 , and $1658 \mathrm{~cm}^{-1}$ (Suppl. Fig. S3b) (Rygula et al. 2013) and reflect the chromosomal material mostly in the polar region. Lipids are also found in the centre of the zygospore (Fig. 6a), but also as a continuous layer surrounding the cell (Fig. 6b). The endmember spectrum showed bands at 1658, 1442 and $1304 \mathrm{~cm}^{-1}$, which were assigned to lipids (Wu et al. 2011; Prats-Mateu et al. 2016) (Fig. 6c). This layer in the mesospore merged with an aromatic layer, clearly distinguished from each other due to endmembers with different chemical Raman signature (Fig. 6c). The bands at $1628,1600,1450$ and $1296 \mathrm{~cm}^{-1}$ point to an aromatic and lipidic nature (Varsanyi 1969; Prats-Mateu et al. 2016), probably sporopollenin or algaenan (Lutzke et al. 2020; Joseph et al. 2011).The observed high fluorescence in this layer and sensitivity to sample degradation (Suppl. Fig. burnedS3) are typical for aromatic components like lignin (Gierlinger et al. 2012) and sporopollenin (Joseph et al. 2011). Additionally, carbohydrates were visualized as the main components from the endospore to the exospore (Fig. 6b). The corresponding endmember spectrum showed bands for cellulose and hemicelluloses at 1473,1096,1120, 897 and $380 \mathrm{~cm}^{-1}$ (Wiley and Atalla 1987, Gierlinger et al. 2012), while the pectin marker band at $856 \mathrm{~cm}^{-1}$ (Synytsya et al. 2003, Gierlinger et al. 2012) is absent (Fig. 6c).

\section{Discussion}

In the present study, we have gathered numerous morphological and biochemical data to characterize the sexual reproduction process and the zygospores of Mougeotia spp. collected from field samples. a

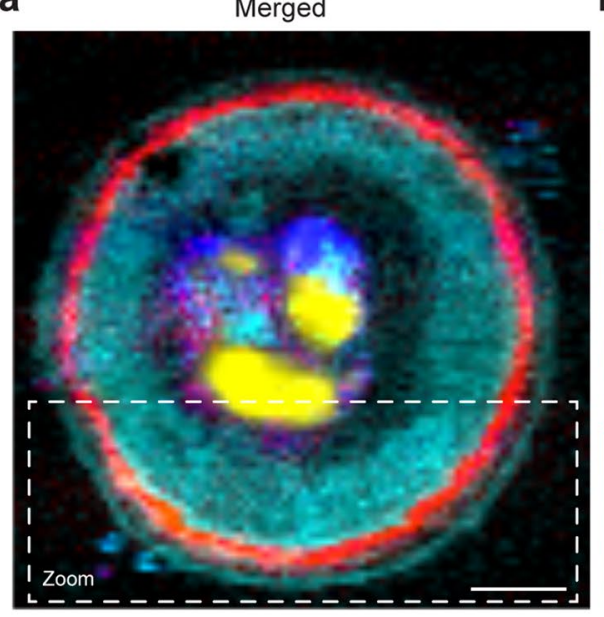

b

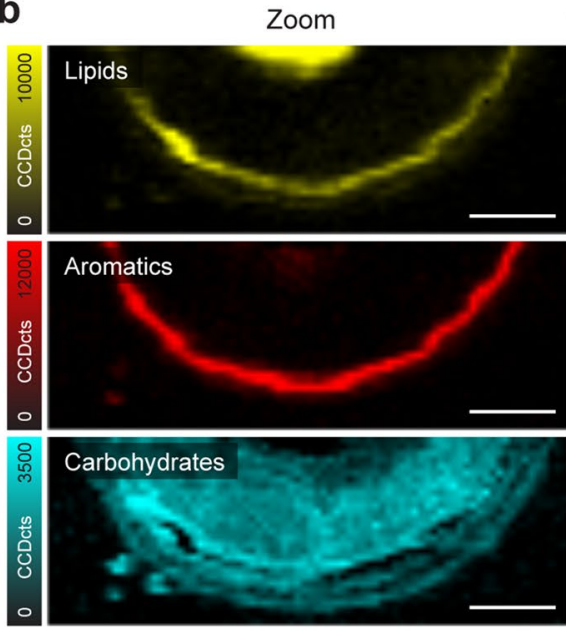

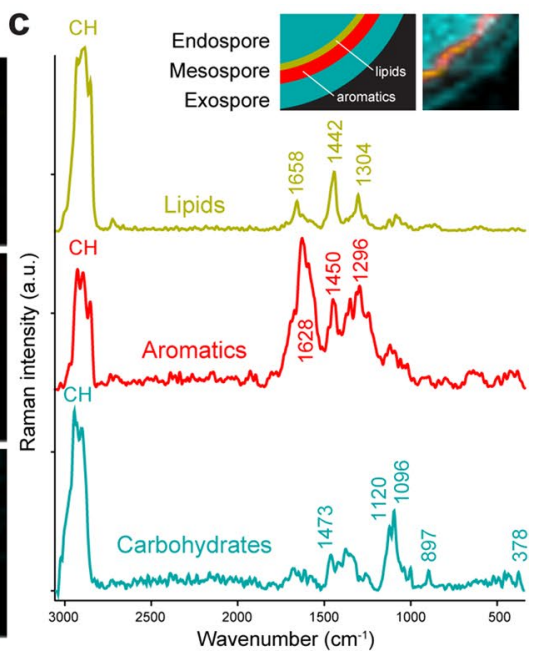

Fig. 6 Raman images of Mougeotia disjuncta reveal aromatic compounds merged with a lipid layer in the mesospore. (a) Merged image of four NMF endmembers including carbohydrates (cyan), lipids (yellow), aromatics (red), and proteins (blue), (b) Detailed NMF anlysis of the multi-layered cell wall visualizes lipids, aromatics and carbo- hydrates, (c) Corresponding endmember spectra show respective bands of the three component classes. Inlay represents the overlay of the aromatics and lipids in the mesospore as a schematic drawing and a section of the images from c as an overlay. Scale bars $5 \mu \mathrm{m}$ 


\section{Species identification using morphological features}

The two Mougeotia species investigated were determined as $M$. parvula and $M$. disjuncta based on morphological characteristics. Both species perform an isogamous extragametangial scalariform conjugation. While zygospores of $M$. parvula stay attached to their parental filaments, zygospores of $M$. disjuncta are surrounded by a thick pectic layer and the conjugation tube often dissolves during maturation. The two species were furthermore distinguishable based on the mesospore characteristics. M. parvula exhibits spherical zygospores, with no distinctive surface structure while $M$. disjuncta forms lenticular zygospores displaying a prominent suture and a punctated mesospore. Both species belong to the section Mesocarpus, which includes species with sexual reproduction and sporangium formation between the two gametangia without their division, as observed in the present study (Gauthier-Lièvre 1965; Kadlubowska 2009). The morphological and cytological features of vegetative filaments allow to identify only the genus. However, the morphological species assignment of Zygnematophyceae is possible based on conjugation characteristics and zygospore properties. In the present study, the most reliable zygospore characteristic was the surface structure of mature cells. In contrast, their size showed a substantial level of variation, as it depends on the total volume of the two conjugating parental cells, which can vary considerably (Czurda 1930; Allen 1958; Poulícková et al. 2007). We observed strong differences in surface structure, whereas the mesospore of both investigated species exhibited a brown coloration. Phylogenetic analyses of the closely related genera Zygnema suggested the mesospore color to be an important criterion for Zygnema classification (Stancheva and Sheath, 2012).

\section{Maturation of zygospores}

The 4-month maturation process led to the loss of chlorophyll and the formation of a multilayered thick cell wall in both species. Older zygospores accumulated storage compounds (mostly lipid bodies in the centre of the cell) as detected by Raman spectroscopy. The observed changes were similar to those described during the transition of vegetative cells into pre-akinetes in Zygnema sp. (Arc et al. 2020). These resting spores, which are still attached to the filament, show a change in chloroplast morphology and ultrastructure, degradation of starch grains and an accumulation of lipid bodies. Metabolite profiling of pre-akinetes showed a re-allocation of photosynthetically fixed carbon into storage instead of growth (Arc et al. 2020). Most likely, similar re-allocation occurred during the investigated zygospore maturation, as TEM micrographs of fairly young zygospores indeed showed chloroplasts and starch grains that degraded during maturation. The lipid bodies were spread throughout the cell lumen or accumulated close to the endospore in the mature state. This peripheral organization is suspected to be part of the maturation process and zygospores with this lipid arrangement may represent an advanced stage.

\section{Structure and chemistry of the zygospore wall}

The mature cell wall of all observed zygospores depicted three major layers and an additional fourth lipid-like layer, which was located between the endo- and mesospore. The endo- and exospore contained various polysaccharides (Poulícková et al. 2007), which was congruent with their loose fibrillar appearance and our detection of carbohydrates in the wall. The Raman signature of the mature zygospore wall confirmed bands attributed to cellulose and hemicellulose, but the pectin marker band at $856 \mathrm{~cm}^{-1}$ was not detected (Fig. 6b-c). This means pectin is not or only in very low amounts present within the mature zygote wall. The endospore was denser and more homogeneous than the fairly loose exospore, indicating a different composition and/ or structural organization of the components when compared with the exospore. Way less is known about the chemical composition of the intermediate mesospore, which might be the foundation of the zygospores' remarkable resistance. The mesospore is ornamented, coloured and defines the zygospore surface structure, which is suggested by our TEM investigations and previous studies (Poulícková et al. 2007; Kadlubowska 2009). In mature zygospores, the mesospore exhibits a very high electron density and a "floe-like" inner structure. While earlier studies described a chitinous deposit in the "mesospore", more recent data suggested lipids and a sporopollenin-like material (Tiffany 1923; Blokker 2000; Poulícková et al. 2007). Using Raman spectroscopy, a mixture of lipids and aromatics is suggested for the mesospore and also a continuous layer of lipids adjacent to the mesospore in both Mougeotia species. This structure could represent the lipid-like layer observed in TEM micrographs or support the hypothesis of Poulícková et al. (2007), stating the occurrence of lipids as part of the mesospore. The latter interpretation is supported by our Raman studies which depicted a merge of the lipid layer with a more aromatic layer. The aromatic compounds might reflect a sporopollenin-like material, termed algaenan, as suggested by previous studies (Tiffany 1923; Blokker 2000; Poulícková et al. 2007). Both sporopollenin and algaenan, are resistant biomacromolecules, which differ in their autofluorescence characteristics, location and synthesis (Versteegh and Blokker 2004; Poulícková et al. 2007). Sporopollenin is a chemically highly inert biopolymer found in pollen grains and spores (Kim and Douglas 2013). Despite its importance in gamete protection, its chemical structure was resolved only recently (Li et al. 2019). Sporopollenin likely contains both ester and 
acetate cross-linkages, contributing to its superior chemical inertness (Li et al. 2019). Based on FT-IR and XPS spectroscopy the sporopollenin in plants was revealed to consist primarily of trans-4hydroxycinnamic and fatty acid, while common methods of sporopollenin isolation result in chemical derivatization (Lutzke et al. 2020). The potential to reveal plant chemistry in situ with FT-IR and Raman spectroscopy becomes clear and continuing research with different treatment (chemical or physical) as well as following development will give further detailed insights into zygospore cell wall cemistry. Algaenans are a series of closely related acid- and base-resistant aliphatic biomacromolecules, whose specific structures are still largely unknown (Tegelaar et al. 1989; Versteegh and Blokker 2004; Kodner et al. 2009). A chemical structure analysis of algaenans from the chlorophytic freshwater algae Tetraedron minimum, Scenedesmus communis and Pediastrum boryanum suggests that it contains long-chain even-carbon-numbered $\omega 9$-unsaturated $\omega$-hydroxy fatty acid monomers with intermolecular ester linking and ether cross-linking (Blokker et al. 1998). More recent studies on Nannochloropsis oculata (Ochrophyta) confirm previous findings of inter-linked mid-chain alkyl diols as core element of algaenan (Zhang and Volkmann, 2017). While, there is no clear evidence of algaenan in vegetative cells of Spirogyra, Zygnema or Mougeotia, it was detected in zygospores of Spirogyra (Wurdack 1923; Tiffany 1923; Zelibor et al. 1988; Blokker 2000; Versteegh and Blokker 2004; Kodner et al. 2009). This indicates that algaenan might be restricted to the walls of sexually formed zygospores. In this aspect, Zygnematophyceae resemble land plants, where special resistant biomacromolecules such as sporopollenin are absent in most cell types and restricted to spore and pollen walls.

\section{Compositional changes of Mougeotia spp. cell walls during conjugation}

The vegetative cell wall compositions of Zygnematophyceae and land plants show considerable similarities (Sørensen et al. 2011; O'Rourke et al. 2015), underlining that land plants inherited cell wall features from their green algal ancestors (Harholt et al. 2016; Jiao et al. 2020). We confirmed that major land plant cell wall components occur in $M$. disjuncta: Microarray profiling, which detects glycan epitopes recognised by antibodies and other probes, verified the presence of HG, RGI, xyloglucans, xylans, callose, AGPs and extensins.

Knowledge on the cell wall composition of Zygnematophyceae during conjugation is scarce. While some studies mainly used unspecific dyes or auto-fluorescence properties (Poulícková et al. 2007; Stancheva et al. 2016) others found binding of lectins to structures emerging during conjugation. For example, the lectins Concanavalin A (CA; binding terminal $\alpha$-D-mannose and -glucose) and Ricinus сотmunis agglutinin (RCA; galactose and $\mathrm{N}$-acetylgalactosamin) strongly labelled papillae and contact zones between papillae in Spirogyra varians and S. castanacea (Yoon et al. 2009; Ikegaya et al. 2012). Concavalin A strongly labelled papillae of conjugating Closterium sp. (Abe et al. 2016). In contrast, papillae in Zygnema cruciatum were only weakly labelled by CA and RCA (Kim et al. 2007). The lectin soybean agglutinin (SBA; N-acetylgalactosamin) strongly bound to papillae and contact zones between papillae in $Z$. cruciatum and $S$. castanacea, while binding was absent in $S$. varians. Another lectin, Ulex europaeus agglutinin (UEA; L-fucose), bound to vegetative filaments of $Z$. cruciatum but a signal was absent in papillae. In contrast, UEA binding was absent in $S$. varians filaments, but occurred in papillae. This suggests that the cell wall composition of both conjugating structures and vegetative filaments can differ significantly between genera and even between species. Moreover, we tested binding of nine lectins to Mougeotia cell walls - including CA, RCA and SBA - but none of them produced appreciable signals. This supports the idea of genera-specific cell wall differences. Interestingly, the above-mentioned authors found binding of lectins to conjugation tubes that recognize $\mathrm{N}$-acetylgalactosamin (RCA, SBA). This suggests the presence of one or more unknown cell wall compounds (glycoprotein and/or poly-/oligosaccharide), which only emerge during the conjugation process. Further studies may mine recently published Zygnematophyceae genomes for the repertoire of glycosyltransferases, potentially discovering new cell wall components that are crucial for sexual processes, as these components might mediate the recognition and adhesion between conjugating filaments (Kim et al. 2007; Abe et al. 2016). This may also address the question, whether small differences in the cell wall composition of papillae as recognized by lectins help avoiding the establishment of conjugation tubes between incompatible species and thus prevent wasting metabolic energy by building non-functional conjugation tubes.

In contrast to Spirogyra spp., Mougeotia lacks lectin epitopes in conjugation tubes. However, they both contain callose (Fig. 5g; Yamada et al. 2003), corroborating the role of callose in building up dynamic cell wall structures such as pollen tubes (Schoenaers et al. 2017), repair events (Eggert et al. 2014) or cell plates (Verma 2001). We furthermore found abundant binding of HG probes to conjugation tubes and zygospores. HG was detected in the exospore and the stained material was removable by pectate lyase. Furthermore, the outer zygospore layers contained RGI and staining protruded into the gelatinous sheath surrounding the zygospore. The abundant occurrence of charged polysaccharides and cations (e.g. $\mathrm{Ca}^{2+}$ mediating HG probe binding) might facilitate hydration of the amorphous outer cell wall layers, all of which might 
increase the water holding capacity of cells (Herburger et al. 2019) and allow for substrate adhesion (Domozych et al. 2007). Interestingly, outer zygospore wall layers contained AGPs, which are considered key adhesion molecules in Zygnematophyceae (Palacio-López et al. 2019). The capability of zygospores to adhere to their substrate might be important for successful germination within the population, as young filaments emerging from zygospores are sensitive to desiccation stress (Herburger et al. 2019) and airborne germination would bear the risk of exposing filaments to water scarcity and potentially terminate filament growth.

The cell walls of $M$. disjuncta filaments exhibted a complex architecture. While HG probes bound to both cross and longititunal cell walls, RGI was mostly restrited to cross cell walls. We also detected xyloglucan eipitopes in cross cell walls. Xyloglucan epitopes were also found in cross and longitudinal cell walls of Zygnema spp. (Herburger et al. 2018). Furthermore, protein extracts prepared form Zygnema spp. contained xyloglucan-remodelling enzymes (Herburger et al. 2018). However, unambiguous biochemical evidence for the presence of xyloglucan is still missing in Zygnemtophyceae, despite there is some indication that xyloglucan-like polysaccarides are involved in cell-cell attachement (Ikegaya et al. 2008). This has to be seen crictically as the the presence of the diagnostic isoprimeverose and xyloglucan oligosaccharides releasable by driseleas and xyloglucan-specific endoglucanases/celluloses, respectively, were not confirmed in Charophytes (Popper and Fry 2003; O'Rourke et al. 2015). This again highlights the relevance of studying a broad range of algal species and genera to gain a more comprehensive insight into algal cell wall architectures.

The present study provides a detailed description of the sexual reproduction morphology of two Mougeotia spp. as well as a thorough analysis of the cell wall composition and ultrastructure of the zygospore walls. The multi-layered nature of the cell wall was demonstrated by diverse microscopic techniques. The zygospores were surrounded by a polysaccharide-rich endospore, a massive electron dense mesospore and a thin polysaccharide rich exospore. Between the endo- and mesospore, an additional fourth lipid-like layer was shown by transmission electron microscopy. RAMAN analysis detected aromatic compounds next to an enrichment of lipids in the mesospore, the former most likely representing algaenan or a sporopollenin-like material. Zygospores of different developmental stages contained epitopes of major land plant cell wall components like pectins (e.g. HG), hemicelluloses, (e.g. xyloglucan, xylans) and glycoproteins (AGPs, extensins). In conclusion, these results indicate that the resistant structure of zygospores is attributed to a major reorganization of the cell wall that comprises the formation of special components, not found in vegetative cells.
Supplementary Information The online version contains supplementary material available at https://doi.org/10.1007/s00709-021-01659-5.

Acknowledgements We thank Werner Kofler for the SEM-preparations and Sabrina Obwegeser, MSc (both University of Innsbruck, Austria) for the expert technical help in TEM sectioning and parts of the image generation. Moreover, we thank Dr. Jozef Mravec for supplying OG7$13^{\mathrm{AF} 488}$ probes and Jeanett Hansen (both University of Copenhagen, Denmark) for the excellent technical help during CoMPP experiments.

Author contribution $\mathrm{CP}$ conducted the sampling, light-, confocal- and electron microscopy and wrote the draft manuscript. KH performed and interpreted the CoMPP analysis and immuno-staingings. MN and MF performed and interpreted RAMAN spectroscopy, NG analysed and interpreted the RAMAN data. AH designed and supervised the study, analysed and interpreted the data. All authors participated in manuscript writing and approved the final version of the manuscript.

Funding Open access funding provided by University of Innsbruck and Medical University of Innsbruck. The study was supported by the Austrian Science Fund project I 1951-B16 and P 34181-B to AH, the Villum Foundation project 00023089 to $\mathrm{KH}$ and the Austrian Science Fund START project Y-728-B16 to NG.

Data availability All data that support the findings of this study are available within the article; raw data are available on request from the corresponding author.

Code availabilty Not applicable.

\section{Declarations}

Ethics approval and consent to participate Not applicable.

Consent for publication Not applicable.

Conflict of interest The authors certify that there are no conflicts of interest/competing interests in the subject matter or materials discussed in this manuscript.

Open Access This article is licensed under a Creative Commons Attribution 4.0 International License, which permits use, sharing, adaptation, distribution and reproduction in any medium or format, as long as you give appropriate credit to the original author(s) and the source, provide a link to the Creative Commons licence, and indicate if changes were made. The images or other third party material in this article are included in the article's Creative Commons licence, unless indicated otherwise in a credit line to the material. If material is not included in the article's Creative Commons licence and your intended use is not permitted by statutory regulation or exceeds the permitted use, you will need to obtain permission directly from the copyright holder. To view a copy of this licence, visit http://creativecommons.org/licenses/by/4.0/.

\section{References}

Abe J, Hori S, Sato M, Hiroyuki S (2016) Concanavalin A disrupts the release of fibrous material necessary for zygospore formation of a unicellular charophycean alga, Closterium peracerosum-strigosum-littorale complex. Front Plant Sci 7:1040. https://doi.org/10. 3389/fpls.2016.01040 
Allen MA (1958) The biology of a species complex in Spirogyra. Dissertation. Indiana University, Bloomington (USA)

Arc E, Pichrtová M, Kranner I, Holzinger A (2020) Pre-akinete formation in Zygnema sp. from polar habitats is associated with metabolite re-arrangement. J Exp Bot 71:3314-3322. https://doi.org/10. 1093/jxb/eraa123

Becker B (2013) Snow ball earth and the split of Streptophyta and Chlorophyta. Trends Plant Sci 18:180-183. https://doi.org/10. 1016/j.tplants.2012.09.010

Blokker P (2000) Structural analysis of resistant polymers in extant algae and ancient sediments. Geol Ultraiectina 193:1-145

Blokker P, Schouten S, van den Ende H, de Leeuw JW, Hatcher G, Sinninghe Damsté JS (1998) Chemical structure of algaenans from the fresh water algae Tetraedron minimum, Scenedesmus communis and Pediastrum boryanum. Org Geochem 29:1453-1468. https://doi.org/10.1016/S0146-6380(98)00111-9

Cheng S, Xian W, Fu Y et al (2019) Genomes of subaerial Zygnematophyceae provide insights into land plant evolution. Cell 179:10571067.e14. https://doi.org/10.1016/j.cell.2019.10.019

Czurda V (1930) Experimentelle Untersuchungen über die Sexualitätsverhältnisse der Zygnemalen. Beih bot Zentralbl 47:15-68

Domozych DS, Elliott L, Kiemle SN, Gretz MR (2007) Pleurotaenium trabecula, a desmid of wetland biofilms: the extracellular matrix and adhesion mechanisms. J Phycol 43:1022-1038. https://doi. org/10.1111/j.1529-8817.2007.00389.x

Domozych DS, Sørensen I, Popper ZA et al (2014) Pectin metabolism and assembly in the cell wall of the charophyte green alga Peniummargaritaceum. Plant Physiol 165:105-118. https://doi.org/10. 1104/pp.114.236257

Eggert D, Naumann M, Reimer R, Voigt CA (2014) Nanoscale glucan polymer network causes pathogen resistance. Sci Rep 4:4159. https://doi.org/10.1038/srep04159

Fry SC, York WS, Albersheim P et al (1993) An unambiguous nomenclature for xyloglucan-derived oligosaccharides. Physiol Plant 89:1-3. https://doi.org/10.1111/j.1399-3054.1993.tb01778.x

Gauch HG (1966) Studies on the life cycle and genetics of Zygnema. Master Thesis. Cornell University

Gauthier-Lièvre L (1965) Zygnemacées africaines. In: Nova Hedwigia, 20th edn. Weinheim, Germany, pp 1-210

Gierlinger N, Keplinger T, Harrington M (2012) Imaging of plant cell walls by Confocal Raman microscopy. Nat Protoc 7:1694-1708

Gierlinger N (2018) New insights into plant cell walls by vibrational microspectroscopy. Appl Spectrosc Rev 53:517-551

Grote M (1977) Über die Auslösung der generativen Fortpflanzung unter kontrollierten Bedingungen bei der Grünalge Spirogyra majuscula. Z Pflanzenphysiol 83:95-107

Harholt J, Moestrup Ø, Ulvskov P (2016) Why plants were terrestrial from the beginning. Trends Plant Sci 21:96-101. https://doi.org/ 10.1016/j.tplants.2015.11.010

Herburger K, Holzinger A (2016) Aniline blue and calcofluor white staining of callose and cellulose in the streptophyte green algae Zygnema and Klebsormidium. Bio-protocol 6:e1969. https://doi. org/10.21769/BioProtoc.1969

Herburger K, Ryan LM, Popper ZA, Holzinger A (2018) Localisation and substrate specificities of transglycanases in charophyte algae relate to development and morphology. J Cell Sci 131:jcs203208. https://doi.org/10.1242/jcs.203208

Herburger K, Xin A, Holzinger A (2019) Homogalacturonan accumulation in cell walls of the green alga Zygnema sp. (Charophyta) increases desiccation resistance. Front Plant Sci 10:540. https:// doi.org/10.3389/fpls.2019.00540

Holzinger A, Karsten U, Lütz C, Wiencke C (2006) Ultrastructure and photosynthesis in the supralittoral green macroalga Prasiola crispa (Lightfoot) Kützing from Spitsbergen (Norway) under UV exposure. Phycologia 45:168-177. https://doi.org/10.2216/ $05-20.1$
Ikegaya $\mathrm{H}$, Nakase T, Iwata K, Tsuchida $\mathrm{H}$, Sonobe S, Shimmen T (2012) Studies on conjugation of Spirogyra using monoclonal culture. J Plant Res 125:457-464. https://doi.org/10.1007/ s10265-011-0457-3

Ikegaya H, Hayashi T, Kaku T, Iwata K, Sonobe S (2008) Shimmen T (2008) Presence of xyloglucan-like polysaccharide in Spirogyra and possible involvement in cell-cell attachment. Phycol Res 56:216-222. https://doi.org/10.1111/j.1440-1835.2008.00503.x

Jiao C, Sørensen I, Sun X et al (2020) The Penium margaritaceum genome: hallmarks of the origins of land plants. Cell 181:10971111.e12. https://doi.org/10.1016/j.cell.2020.04.019

Joseph V, Schulte F, Rooch H, Feldmann I, Dörfel I, Österle W, Panne U, Kneipp J (2011) Surface-enhanced Raman scattering with silver nanostructures generated in situ in a sporopollenin biopolymer matrix. Chem Commun 47:3236-3238. https://doi. org/10.1039/c0cc05326k

Kadlubowska JZ (2009) Süßwasserflora von Mitteleuropa, Bd. 16: Chlorophyta VIII. Springer Spektrum, Jena, Stuttgart, New York, pp 19-36, 42, 47, 82

Kim GH, Yoon M, West JA, Klochkova TA, Kim S-H (2007) Possible surface carbohydrates involved in signaling during conjugation process in Zygnema cruciatum monitored with fluorescein isothiocyanate-lectins (Zygnemataceae, Chlorophyta). Phycol Res 55:135-142. https://doi.org/10.1111/j.1440-1835.2007. 00456.x

Kim SS, Douglas C (2013) Sporopollenin monomer biosynthesis in arabidopsis. J Plant Biol 56 https://doi.org/10.1007/ s12374-012-0385-3

Kodner R, Summons R, Knoll A (2009) Phylogenetic investigation of the aliphatic, non-hydrolyzable biopolymer algaenan, with a focus on green algae. Org Geochem 40:854-862. https://doi.org/ 10.1016/j.orggeochem.2009.05.003

Kračun SK, Fangel JU, Rydahl MG, Pedersen HL, Vidal-Melgosa S, Willats WGT (2017) Carbohydrate microarray technology applied to high-throughput mapping of plant cell wall glycans using comprehensive microarray polymer profiling (CoMPP). In: Lauc G., Wuhrer M. (eds) High-throughput glycomics and glycoproteomics. Methods in Molecular Biology, vol 1503. Humana Press, New York. https://doi.org/10.1007/978-1-4939-6493-2_12

Li FS, Phyo P, Jacobowitz J, Hong M, Weng J-K (2019) The molecular structure of plant sporopollenin. Nat Plants 5:41-46. https://doi. org/10.1038/s41477-018-0330-7

Lutzke A, Morey KJ, Medford JI, Kipper MJ (2020) An FT-IR and XPS spectroscopy dataset of Pinus ponderosa sporopollenin and related samples to elucidate sporopollenin structural features. Data $\mathrm{Br} 29$. https://doi.org/10.1016/j.dib.2020.105129

Moller I, Susan EM, Haeger A et al (2007) High-throughput screening of monoclonal antibodies against plant cell wall glycans by hierarchical clustering of their carbohydrate microarray binding profiles. Glycoconj J 25:37-48. https://doi.org/10.1007/ s10719-007-9059-7

Montgomery W, Potiszil C, Watson JS, Sephton MA (2016) Sporopollenin, a natural copolymer, is robust under high hydrostatic pressure. Macromol Chem Phys 217:2494-2500. https://doi.org/ 10.1002/macp. 201600142

Mravec J, Guo X, Hansen AR et al (2017a) Pea border cell maturation and release involve complex cell wall structural dynamics. Plant Physiol 174:1051-1066. https://doi.org/10.1104/pp.16.00097

Mravec J, Kračun SK, Rydahl MG et al (2017b) An oligogalacturonidederived molecular probe demonstrates the dynamics of calciummediated pectin complexation in cell walls of tip-growing structures. Plant J 91:534-546. https://doi.org/10.1111/tpj.13574

O'Rourke C, Gregson T, Murray L, Sadler IH, Fry SC (2015) Sugar composition of the pectic polysaccharides of charophytes, the closest algal relatives of land-plants: presence of 
3-O-methyl-d-galactose residues. Ann Bot 116:225-236. https:// doi.org/10.1093/aob/mcv089

Palacio-López K, Tinaz B, Holzinger A, Domozych DS (2019) Arabinogalactan proteins and the extracellular matrix of charophytes: a sticky business. Front Plant Sci 10:447. https://doi.org/10.3389/ fpls.2019.00447

Popper ZA, Fry SC (2003) Primary cell wall composition of bryophytes and charophytes. Ann Bot 91:1-12. https://doi.org/10. 1093/aob/mcg013

Poulícková A, Zizka Z, Hasler P, Benada O (2007) Zygnematalean zygospores: morphological features and use in species identification. Folia Microbiol 52:135-145. https://doi.org/10.1007/BF029 32152

Prats-Mateu B, Felhofer M, de Juan A, Gierlinger N (2018) Multivariate unmixing approaches on Raman images of plant cell walls: new insights or overinterpretation of results? Plant Methods 14:52. https://doi.org/10.1186/s13007-018-0320-9

Prats-Mateu B, Hauser MT, Heredia A, Gierlinger N (2016) Waterproofing in Arabidopsis: following phenolics and lipids in situ by confocal Raman microscopy. Front Chem 4:7. https://doi.org/10. 3389/fchem.2016.00010

Regensdorff M, Deckena M, Stein M, Borchers A, Scherer G, Lammers M, Hänsch R, Zachgo S, Buschmann H (2018) Transient genetic transformation of Mougeotia scalaris (Zygnematophyceae) mediated by the endogenous $\alpha$-tubulin1 promoter. J Phycol 54:840-849. https://doi.org/10.1111/jpy.12781

Rydahl MG, Hansen AR, Kračun SK, Mravec J (2018) Report on the current inventory of the toolbox for plant cell wall analysis: proteinaceous and small molecular probes. Front Plant Sci 9:581. https://doi.org/10.3389/fpls.2018.00581

Rygula A, Majzner K, Marzec KM, Kaczor A (2013) Raman spectroscopy of proteins: a review. J Raman Spectrosc 44:1061-1076. https://doi.org/10.1002/jrs.4335

Schoenaers S, Balcerowicz D, Costa A, Vissenberg K (2017) The kinase ERULUS controls pollen tube targeting and growth in Arabidopsis thaliana. Front Plant Sci 8:1942. https://doi.org/10. 3389/fpls.2017.01942

Serlin BS, Roux SJ (1984) Modulation of chloroplast movement in the green alga Mougeotia by the $\mathrm{Ca} 2+$ ionophore $\mathrm{A} 23187$ and by calmodulin antagonists. Proc Natl Acad Sci USA 81:6368-6372. https://doi.org/10.1073/pnas.81.20.6368

Simons J, Van Beem AP, De Vries PJR (1984) Induction of conjugation and spore formation in species of Spirogyra (Chlorophyceae, Zygnematales). Acta Bot Neerl 33:323-334. https://doi.org/10. 1111/j.1438-8677.1984.tb01823.x

Sørensen I, Pettolino FA, Bacic A et al (2011) The charophycean green algae provide insights into the early origins of plant cell walls. Plant J 68:201-211. https://doi.org/10.1111/j.1365-313X.2011. 04686.x

Spurr AR (1969) A low-viscosity epoxy resin embedding medium for electron microscopy. J Ultrastruct Res 26:31-43. https://doi.org/ 10.1016/S0022-5320(69)90033-1

Stabenau H, Säftel W (1989) Induction of conjugation in Mougeotia. Can J Bot 67:198-199. https://doi.org/10.1139/b89-282

Stancheva R, Hall JD, Mccourt RM, Sheath RG (2013) Identity and phylogenetic placement of Spirogyra species (Zygnematophyceae, Charophyta) from California streams and elsewhere. J Phycol 49:588-607. https://doi.org/10.1111/jpy.12070

Stancheva R, Herburger K, Sheath RG, Holzinger A (2016) Conjugation morphology of Zygogonium ericetorum (Zygnematophyceae, Charophyta) from a high alpine habitat. J Phycol 52:131-134. https://doi.org/10.1111/jpy.12363

Stancheva R, Sheath R (2012) Systematics of the genus Zygnema (Zygnematophyceae, Charophyta) from Californian watersheds. J Phycol 48:409-422. https://doi.org/10.1111/j.1529-8817.2012. 01127.x
Synytsya A, Copıkova J, Matejka P, Machovic V (2003) Fourier transform Raman and infrared spectroscopy of pectins. Carbohyd Polym 54:97-106

Takano T, Higuchi S, Ikegaya H, Matsuzaki R, Kawachi M, Takahashi F, Nozaki H (2019) Identification of 13 Spirogyra species (Zygnemataceae) by traits of sexual reproduction induced under laboratory culture conditions. Sci Rep 9:7458. https://doi.org/10. 1038/s41598-019-43454-6

Tegelaar EW, de Leeuw JW, Derenne S, Largeau C (1989) A reappraisal of kerogen formation. Geochim Cosmochim Acta 53:3103-3106. https://doi.org/10.1016/0016-7037(89)90191-9

Tiffany LH (1923) A physiological study of growth and reproduction among certain green algae. Ohio State University, Columbus

Varsanyi G (1969) Vibrational spectra of benzene derivatives, 1st edn. Academic Press, New York

Verma DPS (2001) Cytokinesis and building of the cell plate in plants. Annu Rev Plant Physiol Plant Mol Biol 52:751-784. https://doi. org/10.1146/annurev.arplant.52.1.751

Versteegh GJM, Blokker P (2004) Resistant macromolecules of extant and fossil microalgae. Phycol Res 52:325-339. https://doi.org/10. 1111/j.1440-183.2004.00361.x

Wagner G, Haupt W, Laux A (1972) Reversible inhibition of chloroplast movement by cytochalasin B in the green alga Mougeotia. Science 176:808-809. https://doi.org/10.1126/science.176.4036.808

Wagner G, Klein K (1981) Mechanism of chloroplast movement in Mougeotia. Protoplasma 109:169-185. https://doi.org/10.1007/ BF01287638

Wiley JH, Atalla RH (1987) Band assignments in the Raman spectra of celluloses. Carbohydr Res 160:113-129. https://doi.org/10.1016/ 0008-6215(87)80306-3

Wodniok S, Brinkmann H, Glöckner G, Heidel AJ, Philippe H, Melkonian M, Becker B (2011) Origin of land plants: do conjugating green algae hold the key? BMC Evol Biol 11:104. https://doi.org/ 10.1186/1471-2148-11-104

Wu HW, Volponi JV, Oliver AE, Parikh AN, Simmons BA, Singh S (2011) In vivo lipidomics using single-cell Raman spectroscopy. Proc Natl Acad Sci U S A 108:3809-3814. https://doi.org/10. 1073/pnas. 1009043108

Wurdack ME (1923) Chemical composition of the walls of certain algae. Ohio J Sci 23:181-191. http://hdl.handle.net/1811/2207. Accessed 15 Jan 2021

Yamada S, Sonobe S, Shimmen T (2003) Synthesis of a callosic substance during rhizoid differentiation in Spirogyra. Plant Cell Physiol 44:1225-1228. https://doi.org/10.1093/pcp/pcg152

Yamashita T, Sasaki K (1979) Conditions for the induction of the mating process and changes in contents of carbohydrates and nitrogen compounds during the mating process of Spirogyra. J Fac Sci Hokkaido Univ Ser V Bot 11:279-287

Yoon M, Kim MK, Kim GH (2009) Conjugation process in Spirogyra varians monitored with FITC-lectins (Zygnemataceae, Chlorophyta). Algae 24:39-45. https://doi.org/10.4490/ALGAE.2009.24.1.039

Zhang Z, Volkmann JK (2017) Algaenan structure in the microalga Nannochloropsis oculata characterized from stepwise pyrolysis. Org Geochem 104:1-7. https://doi.org/10.1016/j.orggeochem. 2016.11.005

Zelibor JL, Romankiw L, Hatcher PG, Colwell RR (1988) Comparative analysis of the chemical composition of mixed and pure cultures of green algae and their decomposed residues by $13 \mathrm{C}$ nuclear magnetic resonance spectroscopy. Appl Environ Microbiol 54:1051-1060. https://doi.org/10.1128/AEM.54.4.1051-1060. 1988

Publisher's note Springer Nature remains neutral with regard to jurisdictional claims in published maps and institutional affiliations. 